\title{
Representing Race in Graphs: W. E. B. Du Bois, Corporate Bureaucrats, and Visualization Strategies for Change
}

\author{
LUZILDAARCINIEGA \\ UNITED STATES
}

\begin{abstract}
In this paper, I draw together W. E. B. Du Bois and corporate bureaucrats to compare the graphical representation of race across three distinct racial epochs: the Progressive, Civil Rights, and post-1980s neoliberal era. I illustrate how, through visual and rhetorical strategies, corporate bureaucrats extend a Du Boisian legacy in constructing popular knowledge of race and racism. I show how they do this by making whiteness visible through data visualizations and rhetorically bundling them to liberal American values of equal opportunity. In examining them as epistemic and semiotic objects, I argue that graphical representations of race compel the enactment of meaningful strategies seen to challenge racial inequalities in the workplace. Yet, insofar as these are employed to equate racism with the absence of equal opportunity in capitalist firms, I argue, they also mask whiteness and reproduce systemic racism. The graphical representation of race, in effect, reveals how the practices of knowledge production and processes of signification are entangled in everyday corporate bureaucracies. Thus, I suggest that we need to reject analytical binaries that pose a bounded distinction between "business" and "social justice" to extend research into the cultural production and productive enactment of racial materiality.
\end{abstract}

\section{Keywords}

Du Bois; race; racism; data visualization; corporations; equal opportunity

\section{Introduction}

At the turn of the 20th century, W. E. B. Du Bois (1899; 1900) innovatively illustrated demographic data, displaying the socio-economic condition of African Americans in the United States to challenge popular conceptions of racial inferiority. Since then, scholars of color and allies have employed data visualizations to expose the operations of systemic racism in the United States. For example, researchers have written about the impacts of environmental, policing, economic, and housing policies on communities of color by representing race in graphs, maps, and other images (e.g. Benjamin 2019; Bond 2017; Gilmore 2007; Noble 2018; Pulido 2000). While we assume - and to some extent know - that these data visualization practices are effective for creating popular understandings of the complex social, economic, and political phenomena that is racism, we know little of how and why this is the case. We also know less of the cultural role these visualizations play in spaces that are not typically considered activist, such as the corporation.

Copyright (C) 2021 (Luzilda Arciniega). Licensed under the Creative Commons Attribution-NonCommercialNoDerivatives 4.0 International (CC BY-NC-ND 4.0). Available at estsjournal.org.

To cite this article: Arciniega, Luzilda. 2021: "Representing Race in Graphs: W. E. B. Du Bois, Corporate Bureaucrats, and Visualization Strategies for Change." Engaging Science, Technology, \& Society 7.1: 22-47. https://doi.org/10.17351/ests2021.565. 
This paper explores how data visualization is currently "reimagined as a form of accountability and even protest in the age of Black Lives Matter" (Battle-Baptiste and Rusert 2018, 22). Diversity professionals - most of whom are people of color and women and are human resource professionals, diversity officers, business scholars, and management consultants-produce graphs to advocate for increased racial and gender representation among corporate leadership. Since the 1960s, these graphs have been critical components of affirmative action reporting. Using ethnographic and historical data, I draw together W. E. B. Du Bois's and corporate bureaucrats' graphical illustration of racial differences in the workplace, comparing these practices across three distinct racial epochs: the Progressive, Civil Rights, and post-1980s neoliberal era. I draw on two years of ethnographic research conducted among diversity professional networks in the United States from 2014 to 2016 and in 2020 at a non-profit organization, American D\&I, ${ }^{1}$ and at over 50 events, including three national and international diversity conferences. I also draw on archival research, analyzing one company's affirmative action reports: those of the Polaroid Corporation. ${ }^{2}$ I inquire into how diversity "is done" in everyday bureaucratic processes and historically as racial projects (Ahmed and Swan 2006; Omi and Winant 2014).

In examining how graphical representations of race are both epistemic and semiotic objects, I argue that graphical representations of race enable corporate bureaucrats to challenge racial inequalities in the workplace. Yet, insofar as they equate racism with the absence of equal opportunity, they also mask whiteness. By tracing their visual and rhetorical strategies, I illustrate how corporate bureaucrats extend a Du Boisian legacy in constructing popular understandings of race and racism. First, I show how they make some aspects of whiteness - a social, political, and economic phenomenon - visible, which enables them to depict racial hierarchies in the workplace. Second, in rhetorically bundling specific semiotic qualities of graphs with liberal American values of equal opportunity I show how they create new meaning over racial inequality and construct popular understandings of racism. Third, insofar as these graphs are tied to specific cultural values and authorities, I explain these newly meaningful graphical representations of race compel the enactment of institutional practices regarded to address racial inequalities in the workplace.

Social scientists have critiqued diversity management as a field of business expertise that co-opted social justice movements to employ race and gender as sources of capitalist value, govern alreadymarginalized individuals, and reproduce systemic inequities while appearing "to do good." (Ahmed 2012; Berrey 2015; Gordon 1995; Melamed 2006; Mohanty 2003). They highlight that diversity professionals tie diversity to business value by arguing that diverse talent helps organizations identify new markets, innovate products, and after the 2008 economic recession, anticipate political and economic crises (e.g., El-Erian 2016; Thomas 1991). Yet, I contend that the graphical representation of race reveals how the practices of knowledge production and processes of signification are entangled in everyday corporate bureaucracies. As such, scholarship that employs analytical binaries of "social justice" and "business" as separately bounded

\footnotetext{
${ }^{1}$ All names of individuals and organizations are pseudonyms unless obtained through public or archival records. ${ }^{2}$ Baker Library at the Harvard Business School hosts over 100,000 corporate annual reports. At the time of research only Polaroid Corporation made publicly available their affirmative action annual reports.
} 
objects are limited for examining how race and racism are constructed, operationalized, and mobilized across time and space by everyday mundane materiality, such as graphs.

Taking a critical perspective, I further argue that employing graphical representations of race in the corporation inadvertently reproduces power-laden relations that are embedded in capitalist firms. I draw attention to one major purpose of these data visualizations, which is to diversify corporate executive leadership. I show how diversity practices, in particular, are driven by cultural assumptions that if biases were eliminated from capitalist labor markets, people of color could achieve compensation and prestige that are normative to the highest-ranking occupational roles in the corporation. Thus, graphical representations of race employed in corporate cultural processes, I suggest naturalize capitalist market ideologies and systemic racial hierarchies embedded in the structures of corporate firms. Therefore, in attempts to inform the practice of using data visualization to address systemic racism in and beyond the workplace, I draw on scholarship on feminist data visualization, namely on Catherine D'Ignazio and Lauren F. Klein (2016), who beyond asking us to reject analytical binaries, also stressed that we should address the needs of collectives (not just individuals) and embrace a diversity (or plurality) of strategies for creating systemic change.

\section{Data Visualization, Epistemic Objects and Racial Materiality}

Graphs are a type of data visualization. As a pragmatic means to communicate information, they make expertise public by displaying large amounts of data in a concise, clear, easy and quick-to-read manner. For this reason, they are ubiquitous in scientific literature and in everyday business practice (Tilling 1975). They are what Bruno Latour and Steven Woolgar (1979) termed as "inscriptions," which represent material objects in a way that can be used by others. Like maps, graphs have "properties of being mobile, but also immutable, presentable, readable, and combinable with one another" (Latour 1990, 26). Immutable mobiles, Bruno Latour (ibid.) wrote, retain a culturally coherent form and content and, hence, are able to circulate across time and distance. Data visualizations also are "epistemic things," objects with a force that help drive knowledge production (Rheinberger 1997). As social scientists of scientific imaging and visualization have shown, data visualizations are central to the production of scientific knowledge and do more than just represent, they achieve things in the world (Burri and Dumit 2008; Coopmans et al. 2014; Latour 1987; Latour and Woolgar 1979; Lynch and Woolgar 1990).

Social scientists have shown that data visualizations make the invisible visible and that this is cultural work (Aman and Knorr-Cetina 1988; Knorr-Cetina and Amann 1990; Lynch 1985a). Much of this literature has focused on how laboratory scientists produce visuals of biological, chemical, and physical phenomena that cannot be seen with the naked eye (Calvillo 2019; Cambrosio et al. 2005; Hankins 2000; Kaiser 2009; MacKenzie 2013; Vertesi 2014). Scholars have also shown that visibility is entangled with rhetoric and argumentation as visualizations convey ideas that can challenge popular beliefs ( 2014; Tufte 1997). For example, Alberto Cambrosio, Daniel Jacobi, and Peter Keating (2005) wrote that Linus Pauling used a series of images to convince academic skeptics that the fit between two molecules"molecular complementariness" - is the basis of life by illustrating the "lock and key" mechanisms for antibody-antigen reactions. Similarly, Klaus Hentschel (2014) explained that $18^{\text {th }}$ century astronomer, William Herschel, used graphs to plot thermometric heat along a visible spectrum that ranged from violet, indigo, blue, green, yellow, orange, and red to invisible lights. Difficult to explain, his visuals depicted the progression of light from visible to invisible spectrums, ultimately convincing his audience of the existence 
of infrared light. Little attention, however, has been placed on how data visualizations help make social, economic, and political phenomena visible in ways that help construct meaningful and useful concepts.

In constructing meaning over otherwise invisible phenomena, data visualizations also achieve things in the world. Visualizing viruses, for instance, can incite cultural fear and anxiety over infectious diseases, and hence, a desire to combat them (Buiani 2014). Images also stabilize facts, as well as shape and even make human action normative (Burri 2012; Dumit and de Laet 2014; Garnett 2016; Latour 1987; Lynch 1985b). For instance, science and technology scholars have shown that data visualizations drive organizational change and managerial processes (Quattrone, McLean, and Thrift 2013; Thrift 2005). In the study of financial cultures, Daniel Beunza and David Stark (2004) explained that traders turn the trading room into a laboratory, using graphs, colors on screens, computer instruments and their calculations, and their rivals' "footprints" to calculate whether to buy and sell. Thus, the Dow Industrials and NASDAQ graphs allow stock traders to identify and profit from a "market opportunity" (Beunza and Stark 2004). The role of visual technology in finance is central to how these markets operate; they tame and manage the future (Pryke 2010).

While we know that epistemic objects shape cultural action, studies in the data visualization of race must also account for how race is always-already a meaningful category. Donna Haraway (1997) revealed, for instance, that race is a material-semiotic object of knowledge, whose materiality actively constructs it. For example, craniometric visualizations - which purport to represent data of racial difference acquired through pseudoscientific practices - shaped public, scientific, medical, and legal discourses as centered on conceptions of racial inferiority. Through and beyond Haraway's material-semiotic analytic, scholars have examined the relationship between the racial materiality of race and systemic racism by drawing attention to the construction and operationalization of race in biomedicine and, in particular, genetics (RodríguezMuñiz 2016; Doucet-Battle 2016). Additionally, scholars have shown that social actors do not just subscribe to, but challenge the meanings historically inscribed in material-semiotic objects or racial (semiotic) materiality. Here, I draw attention to Amade M'charek (2013), who showed that racial materiality extends beyond the body, including in criminal report sketches and court documents, and that race is neither fact or fiction, but culturally situated and relationally enacted in practice.

To examine how racial materiality can compel change, I draw on Charles S. Peirce (1958) who wrote that signs and their meaning do not reside in the mind; rather, they are achieved through one's experience in the world. This is, he wrote, because all signs exist in a triadic relationship between the sign, the object to which the sign refers, and the interpretant, which relates sign and object. Webb Keane (2003) drew productively on Peirce (1958) and anthropologist Nancy Munn (1986) to explain how the analysis of semiotic materiality is productive for understanding culture, as it helps us understand how signs exist in a meaningful and compelling relation to cultural values and practices (a semiotic triad). For instance, Munn (ibid.) originally revealed that qualities or "qualisigns" (a quality that is a sign) such as "lightness" represented in things like the weight of a canoe are valuable because they expand the spatial and temporal reach of other valuable goods, such as bracelets and fish, and that this explains why similar, but different practices that are "light" are also valuable. Keane wrote that signs have causal effects, but not because they determine action; rather because signs "are thoroughly enmeshed with the dynamics of social value and authority" (2003, 415). In examining graphical illustrations of race as epistemic and semiotic objects, I trace how they can compel meaningful institutional changes in intended and unintended ways. In what follows, I show first how 
by constructing popular understandings of race and racism, W. E. B. Du Bois's data visualization practices laid the foundation for corporate bureaucrats to advocate for increased workplace racial representation.

\section{W. E. B. Du Bois's Data Visualization Practices}

For much of his academic trajectory, W. E. B. Du Bois was a prolific Black positivist scholar who believed that unbiased scientific inquiry would dismantle scientific and systemic racism (Allen and Jobson 2016; $\underline{\text { Hatch }}$ 2020; Zuberi 2004). In one of the earliest scholarly uses of statistics and the first social scientific study of race, "The Philadelphia Negro" (1899), Du Bois analyzed data from over 5,000 interviews, providing a comprehensive study of African Americans and Black immigrant income, marriage, literacy, crime rates, religious practices, and employment status in Philadelphia. In the time of Plessy v. Ferguson and the rise of eugenics ideology in the United States and abroad, Du Bois used graphs to create scholarly and public understandings of racism in American society that are still employed today.

In a section entitled "The Occupations of Negroes," Du Bois displayed employment data in tables spanning eight full pages before stating that the only way to "grasp the true meaning of these figures" was "by comparing the distribution of occupations among the Negroes with that of the total population of the city" (ibid., 108). He visualized this data in bar graphs, depicting in ascending and descending order the proportion of African Americans employed in five occupational groups, compared to that of the whole population (see figure 1). Du Bois paired this graph with one that breaks down this data analytically in terms of gender (see figure 2). He ordered the bars in ways that highlighted differences across race and gender: almost no Black people were employed in professional services and almost all Black women were employed in domestic services. In comparing these two graphs, Du Bois kept a similar scale, but extended the bar displaying the proportion of Black women in domestic and professional services to the right, making it appear to fall off the chart. He explained that given that most Black women are in one industry, they experience more competition, and as a result, lower wages. Du Bois held no reservations to explain these three graphs as telling one coherent narrative, "The causes of this peculiar restriction in employment of Negroes are twofold: first, the lack of training and experience among Negroes; second, the prejudice of the whites." (ibid., 111).

In these two graphs we see visual and rhetorical strategies that Du Bois and his associates would continue to use in the 1900 Paris Exposition: scaling to make the smallest of African American populations in professional fields visible, categorizing, coloring and ordering to highlight differences across race, as well as rhetorically bundling data visualizations with equal opportunity values. Such strategies would help drive forward new understandings of race and racism. For instance, in this case Du Bois's audience was academic, white, and may have mostly subscribed to popular scientific racism. For him, these graphical representations of race, and more specifically its features, such as differences in the length of the bars, were symbolic of the inequality that he experienced in the world as a Black man (that he would write about his entire life), and representative of the inequality expressed in observations and interviews with Philadelphia African Americans. 


\section{WHOLE POPULATION \\ OF PHILA.}

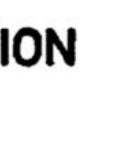

Af

$\mathbf{P}$

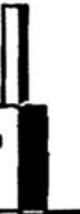

\section{NEGROES \\ OF 7TH. WARD}

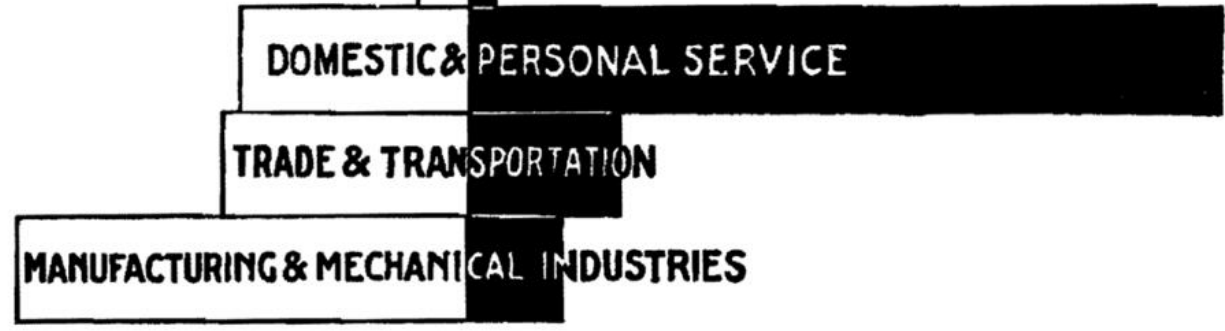

Figure 1. Horizontal bar graph titled "Comparing the Whole Populations with the Negroes of the $7^{\text {th }}$ Ward" (Source Du Bois ibid.).
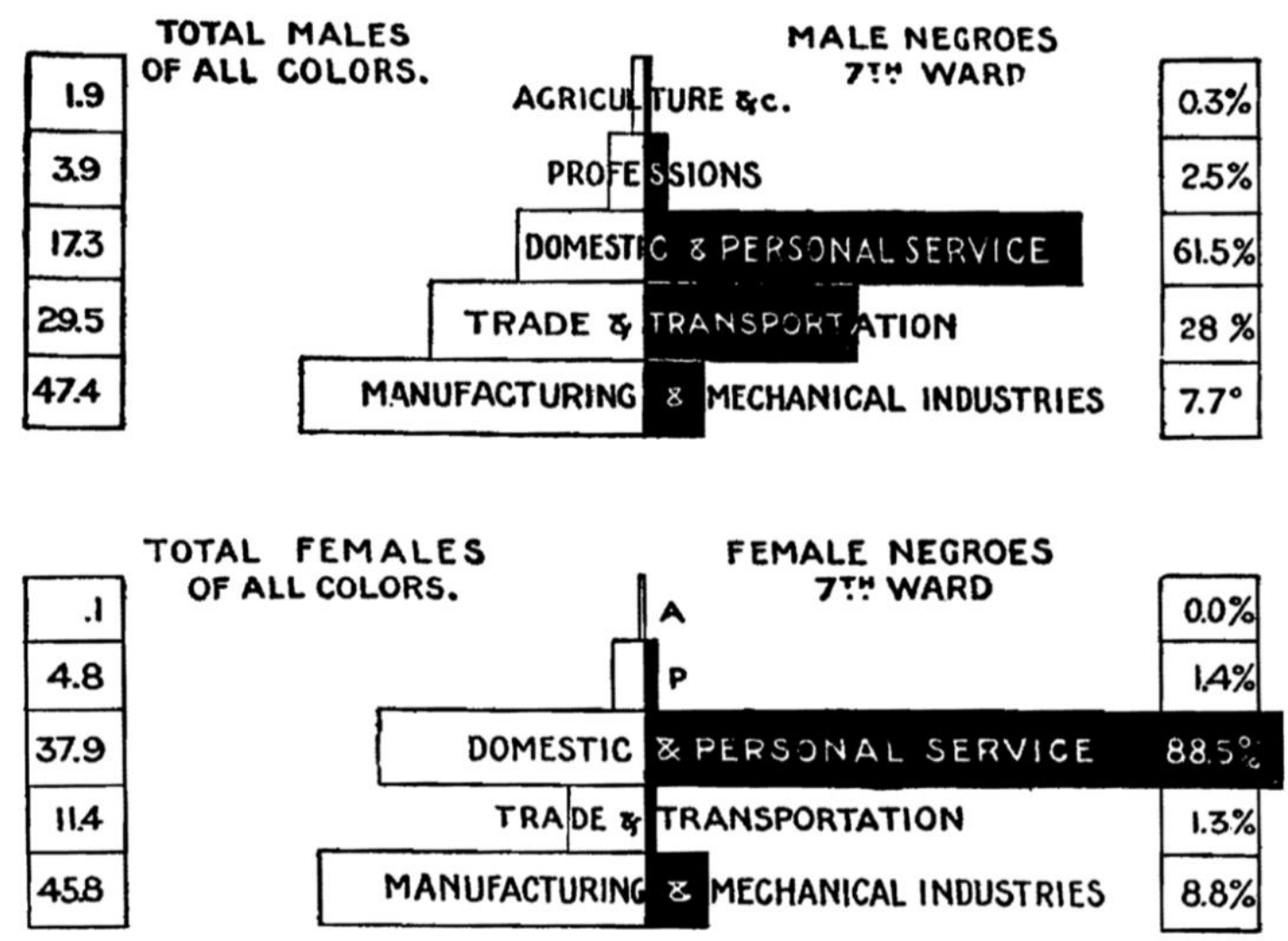

Figure 2. Two horizontal bar graphs titled "Comparing the Whole Populations with the Negroes of the $7^{\text {th }}$ Ward by Sex" (Source ibid.).

Du Bois challenged discourses of Western superiority and possible interpretations of such graphs as evidence of African inferiority by illustrating that Black people were capable of holding positions in professional fields. For instance, with regards to why there were few African Americans in trade unions, he wrote, 
In sections where Negro labor in certain trades is competent and considerable, the trade union welcomes them, as in Western Pennsylvania among miners and iron-workers, and in Philadelphia among cigarmakers; but whenever there is a trade where good Negro workmen are comparatively scarce each union steadfastly refuses to admit Negroes, and relies on color prejudice to keep up the barrier (ibid., 128).

He explained to his white audience that the absence of African Americans in manufacturing was a matter of economics and resulting prejudice. A lack of training, he wrote, drives down the cost of labor and fuels conflict across white union workers and Black non-union workers. ${ }^{3}$ Du Bois, thus, taught his academic audiences a nuanced understanding of systemic racism, writing "a combination of social problems is far more than a matter of mere addition,- - the combination itself is a problem" (ibid., 385).

At the 1900 Paris Exposition, Du Bois foregrounded a colorful graphical display of social analysis, but this time to (re)educate a white popular audience who had attended the world fair to witness the "great achievements" of European civilizations. In a collaboration with students and faculty from Atlanta University, including Booker T. Washington and Thomas J. Calloway, these scholars produced over sixty graphs employing data from a social scientific study conducted in Georgia. In these data visualizations, we see similar strategies as those employed in the Philadelphia study. In "Occupations of Georgia Negroes: Males over 10," Du Bois's team used a bar graph to display the number of African Americans employed in various occupations, organizing the bars in descending order from top to bottom. This illustrated that most African Americans were employed in agriculture and labor, industries associated with slave labor in the South (see figure 3). Du Bois curved the largest bar to conform it to the page, making visible that African Americans occupied some of the most prestigious occupations in Georgia.

Similarly, this last employment-focused visual compares Black and white employment in Georgia (see figure 4). This comparison challenged understandings that only Black men worked in this industry, while highlighting that African Americans were capable but obtained fewer jobs in professions requiring higher education. Employing vivid colors, Du Bois and his team made their graphs attractive and used a color code to highlight differences across white and Black groups. Visibility is important, he said, reflecting on the goals of their exhibit: "It was a Massachusetts lawyer who replied to the Patent Office inquiry, 'I never knew a negro to invent anything but lies;' and yet here is a record of 350 patents granted to Black men since ... [African Americans are] here shown to be studying, examining, and thinking of their own progress and

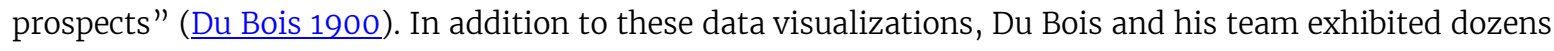
of photographs, over 400 original patents held by African Americans, and more than 200 books written by African American authors.

\footnotetext{
${ }^{3} \mathrm{He}$ also compared the Black experience with that of the Irish, Celts, and Slavs in Europe, arguing that the latter groups overcame socio-economic barriers with full education and citizenship rights. This finding became the topic of an influential area of studies in labor, whiteness, and capitalism (Spero and Harris 1932; Roediger 1999).
} 


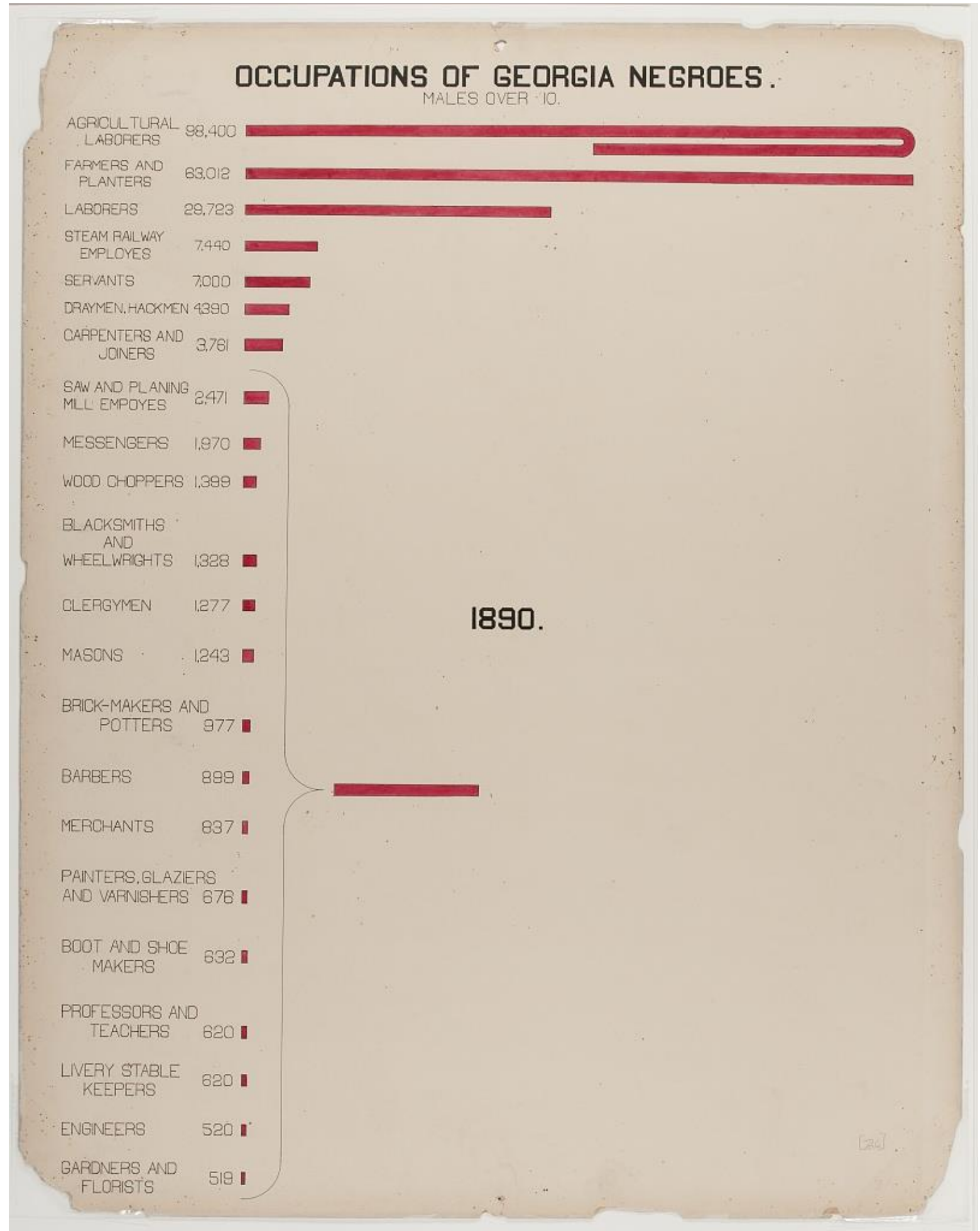

Figure 3. Horizontal bar graph titled "Occupations of Georgia Negroes: Males Over 10." African American Photographs for the Paris Exposition of 1900 (Source Library of Congress website). 


\section{OCCUPATIONS OF NEGROES AND WHITES IN GEORGIA.}

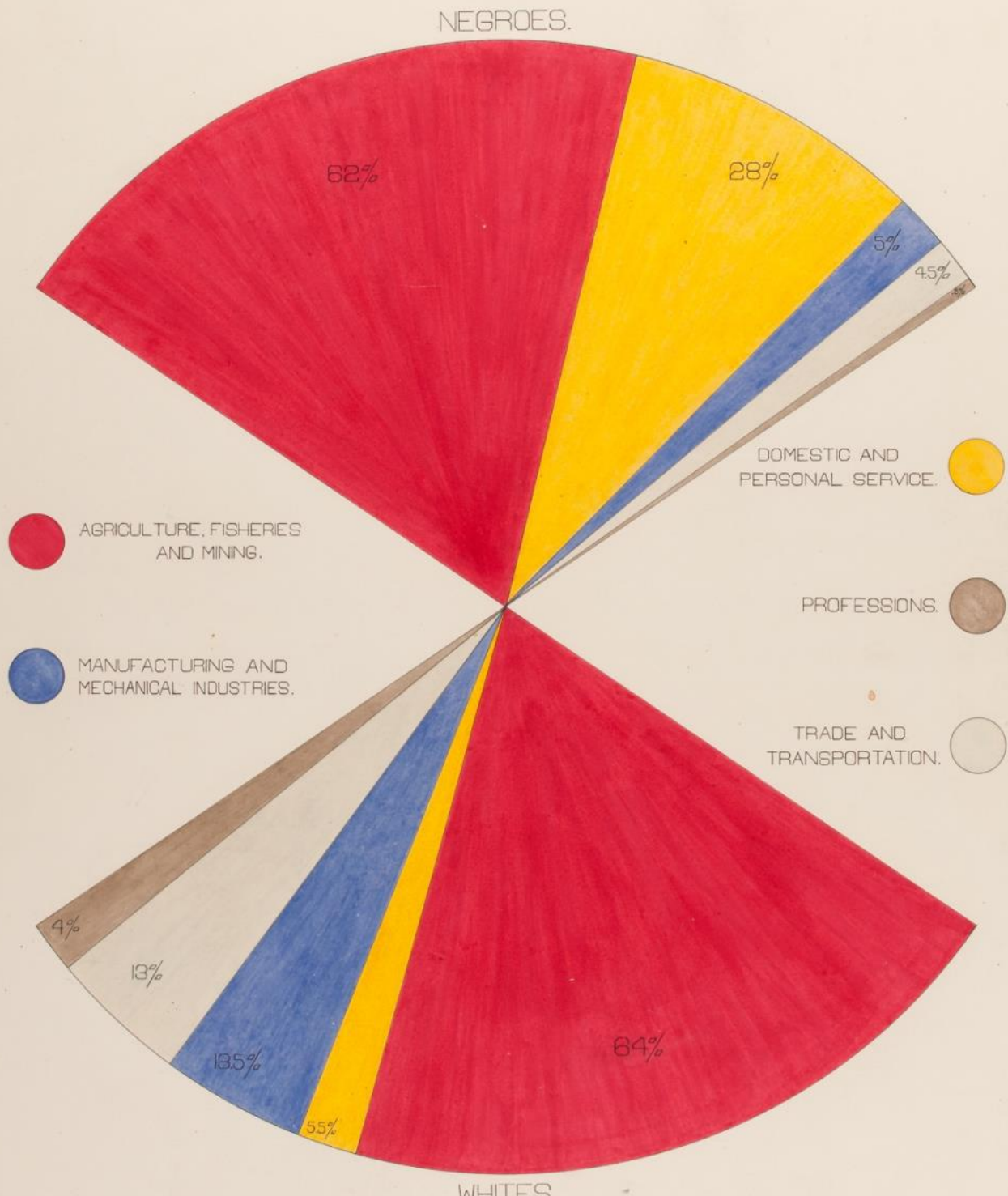

Figure 4. Pie graph titled "Occupations of African Americans and Whites in Georgia." (Source Library of Congress website, ibid.). 
In analyzing archives of his photographs, Shawn Michelle Smith (2004) argued that Du Bois's visual practices of photographing Black middle-class subjects challenged discourses of Black inferiority, yet reproduced aspects of Western culture, such as white respectability, which is structured along class, gender, and racial hierarchies. Here, I illustrate how Du Bois similarly challenged notions of African inferiority through data visualization, and also constructed popular understandings of race and racism by employing Western epistemic strategies, which have semiotic cultural effects. For instance, through graphical representations of race he constructed race as a matter of visual perception, making parallels between colors used to represent black and white populations on paper and their respective skin colors. Drawing on a positivist tradition, he also disentangled subjects from their material world. For instance, he explained that Black impoverished conditions were due to a combination of external social and economic forces and were not an inevitable outcome of a purported natural inferiority. Racism, he convincingly argued, exists as a social fact "out there" and shapes a subject's potential for self-determination. Du Bois employed similar positivist methods used to drive pseudoscientific understandings of African inferiority to disrupt them, replacing them with popular-and academic-understandings of racism that continue to be employed today.

Moreover, through semiotic and epistemic practices, Du Bois positioned African Americans as subjects who despite systemic racism continued their fight for equality. In creating new meanings over the graphical representation of race, he rhetorically bundled illustrations of racial hierarchies with liberal American cultural values of equal opportunity. In the years that followed, scholars of color continued to produce data visualizations in scholarship on the Black struggle for liberation. For example, historian Carter G. Woodson (1918) detailed in bar charts and maps "How the Negroes in the United States have struggled under adverse circumstances to flee from bondage and oppression in quest of a land offering asylum to the oppressed and opportunity to the unfortunate" (ibid., v). Sociologist Franklin Frazer (1932) studied the role of the family in Black socio-economic advancement and Monroe N. Work (1922) and Booker T. Washington produced annual encyclopedias at Tuskegee Institute dedicated to "collecting and circulating information favorable to the Negro" (Guzman 1947, v). In what follows, I show how corporate bureaucrats employed similar data visualization practices in attempts to advocate for equal opportunity in the workplace and the socio-economic inclusion of African Americans in the United States.

\section{Polaroid's Affirmative Action Reports}

In 1961, President John F. Kennedy signed Executive Order 10925, demanding that federal contractors take "affirmative action to ensure that applicants are employed, and employees are treated during employment, without regard to their race, creed, color, or national origin" (Office of Federal Compliance Programs 2020). In 1967, the newly created Equal Employment Opportunity Commission created the Employer Information Report, requiring federal contractors to file the demographics of their workforce every year, detailing the number of employees in different occupational categories ranging from service workers to executives by race and gender. While specific affirmative action practices were eliminated through state and federal lawsuits, corporate employers, such as Polaroid Corporation, continue to produce annual reports to provide evidence of compliance.

As providers of the photographic technology for driver licenses nationwide, Polaroid has been a US defense contractor since World War II. In 1970, human resources (HR) personnel published internally "Equal 
Employment Opportunity: A Report on the Polaroid Program for 1969," and in 1979, "Polaroid Corporation Corporate Affirmative Action Annual Report, July 1978-June 1979)." The 1970 report opens with a letter from Dr. Edwin H. Land, co-founder of the company entitled, "To all Polaroid employees." He wrote:

In addition to making better jobs for those of us who are now here, we must provide new jobs for people not in the company, particularly for people in the Black community. This is a national need and Polaroid as one of the leading companies in the countries must, of course, take its share of the responsibility. I feel very strongly that every one of you should be involved in the planning for taking this responsibility. (Polaroid Report, 1970)

This letter was followed by a fifty-page report using data from six weeks of company audits, including document reviews, surveys, and interviews. Polaroid's HR professionals assessed recruitment, interviewing, hiring, promotion, training, and terminations across race. In the early pages, the authors overviewed the racial demographics within and outside of the company, noting that whereas Boston was $20 \%$ Black, Polaroid's Black workforce composed only $9.8 \%$ of the total. They wrote in a footnote,

The Office of Federal Contract Compliance requires an analysis of all major job categories, 'with explanations if minorities are currently being underutilized in one or more job categories ... . underutilization is defined as having fewer minorities in a particular job category than would reasonably be expected by their availability.'

This footnote was intended to clarify a claim they made in the main text: "It is expected that the distribution of Black employees be even throughout the occupational categories and divisions of the company. (ibid. 15). Through statistics and data visualizations across their reports, HR professionals revealed that Polaroid employed few to no Black employees in higher-paid occupations and a larger proportion of Black employees than white employees in lower-paid occupations. They displayed several pages of tabulated data, summarizing this major claim in a bar chart (see figure 5). They used a dark shading to represent Black employees and an outline of no (or white) color to represent their white employees. This bar graph is, like Du Bois's data visualizations, argumentative, suggesting that white employees earn more than Black employees and that as pay increases, so does the population of white employees - and that the inverse is true for Black employees. While there is no evidence that Polaroid's HR professionals had ever seen his data visualizations, their employment speaks to the popularization of graphical representations of race innovatively produced by Du Bois and his contemporaries. 


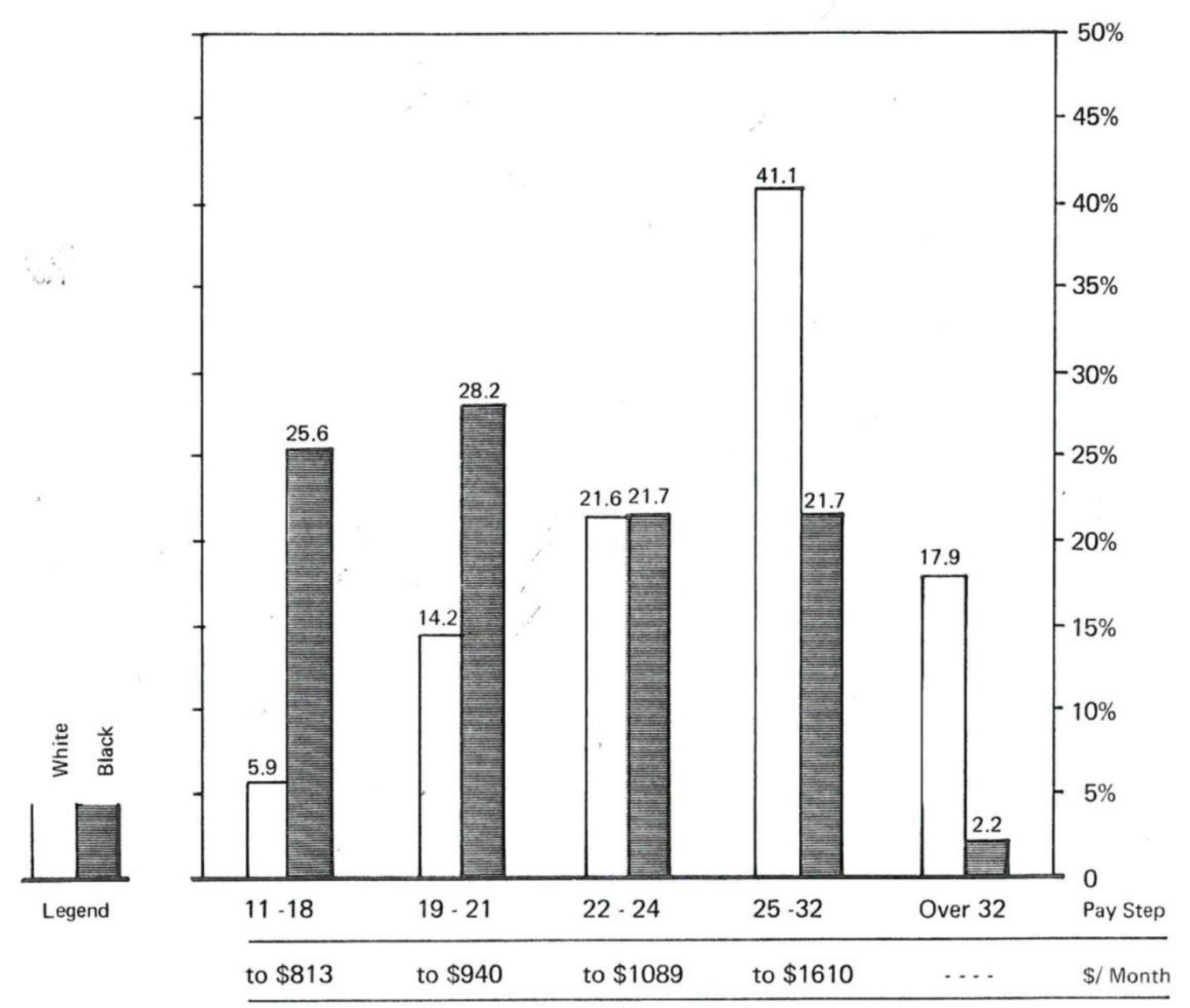

Figure 5. Vertical bar graph, untitled. (Source Harvard Business School Archives, ibid., 22).

In this context of affirmative action reporting, this graph can be interpreted as evidence of non-compliance. Yet, according to the authors, while these graphs revealed racial disparities, they did not reflect racial discrimination enacted by Polaroid. The authors explained, "In all but two [cases], any pay differences could be attributed to length of time on the job and/or length of time in the company" $(1970,21)$. Regardless, they detailed descriptions of their efforts at racial integration: describing their use of hiring and promotion quotas and how they hired a greater proportion of Black applicants, providing examples of marketing materials printed in Black magazines for recruitment, and listing new training programs for Black employees. In their interpretation, Polaroid HR professionals related the graphical representation of race (made up of signs) to the practices they enacted to address the racial inequality these graphs indexed. HR professionals decided that implementing such organizational practices was necessary to show compliance with affirmative action, demonstrating how graphical representations of race can compel the enactment of new practices through situated cultural processes. 
In their 1979 report, Polaroid HR professionals deepened their inquiry by classifying occupations by "Grades" and categorizing employees at the intersections of race and gender (see figure 6). They used pie charts, highlighting the maximum number of individuals that are (and, presumably can be) employed in any one occupational scale as they displayed "Total Population." These graphs again depict Polaroid as employing mostly white men in upper level management occupations, specifically in $90.5 \%$ of them. The second set of pie graphs provides more detail, depicting in text, rather than through the visualization itself, the percentage of Black women employed in these occupational scales: 0 to $0.5 \%$ (see figure 7). Contrasting with the 1970 report, they depicted demographic data in pie graphs. This did the work of implying that in order to increase racial and gender representation, the representation of white men must decrease. These data visualizations, in effect, challenged Dr. Edwin H. Land's original claims that human resource professionals merely needed to create jobs by framing integration as a competition across race and gender. The authors make this implication explicit in entitling their discussion section: "Middle and Senior Management Levels or "Who Holds the Power?"' (Polaroid Corporation Records 1979, IX-5). In the subsequent thirteen pages, the authors explained their efforts to increase representation in leadership, emphasizing programs to recruit high school and college students, for employees to apprentice in high-skill jobs, and to develop career awareness in the community and among their rank-and-file workers.

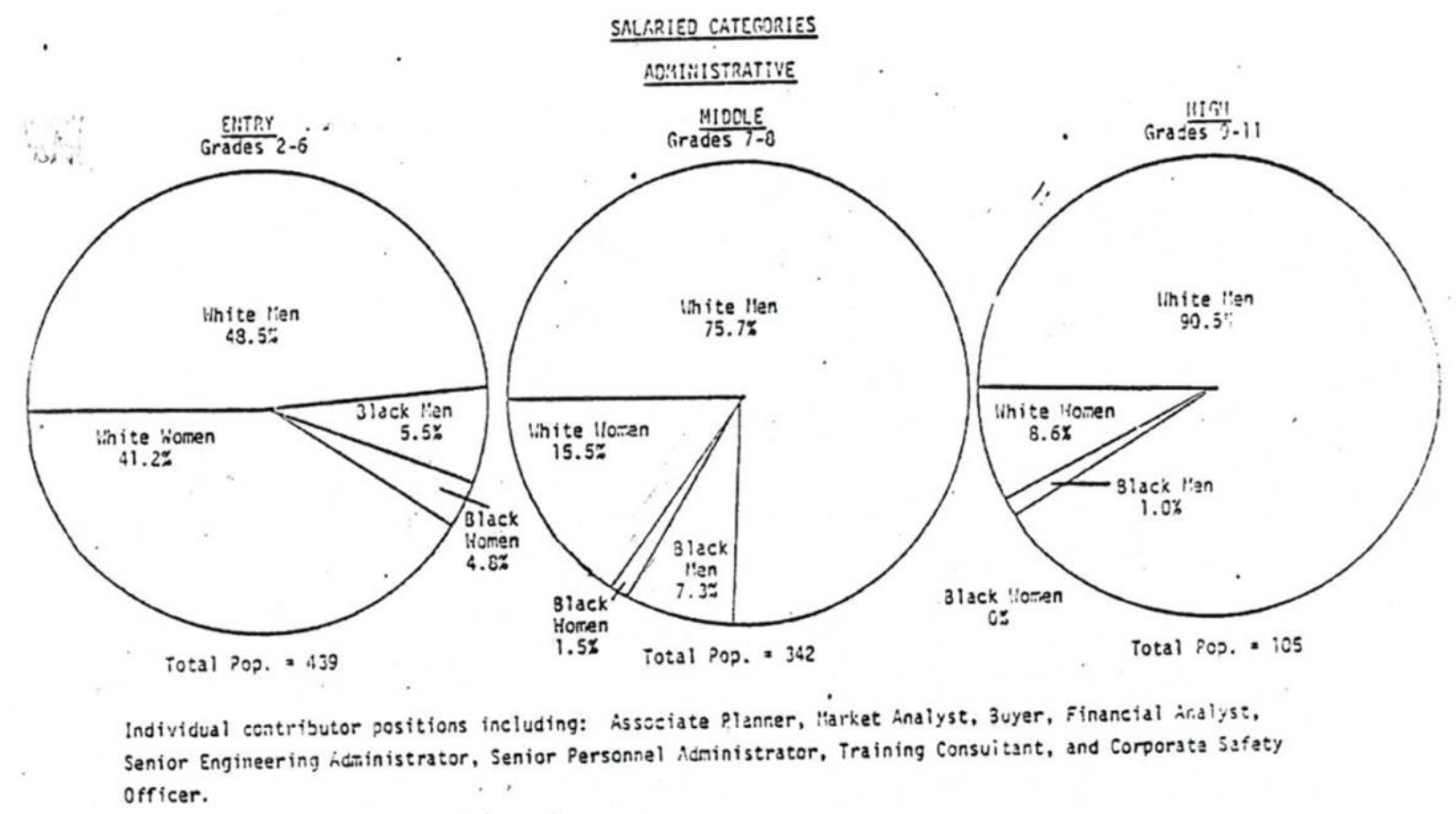

Figure 6. Three pie graphs titled "Salaried Categories: Administrative." (Source Harvard Business School Archives ibid., IX-2). 


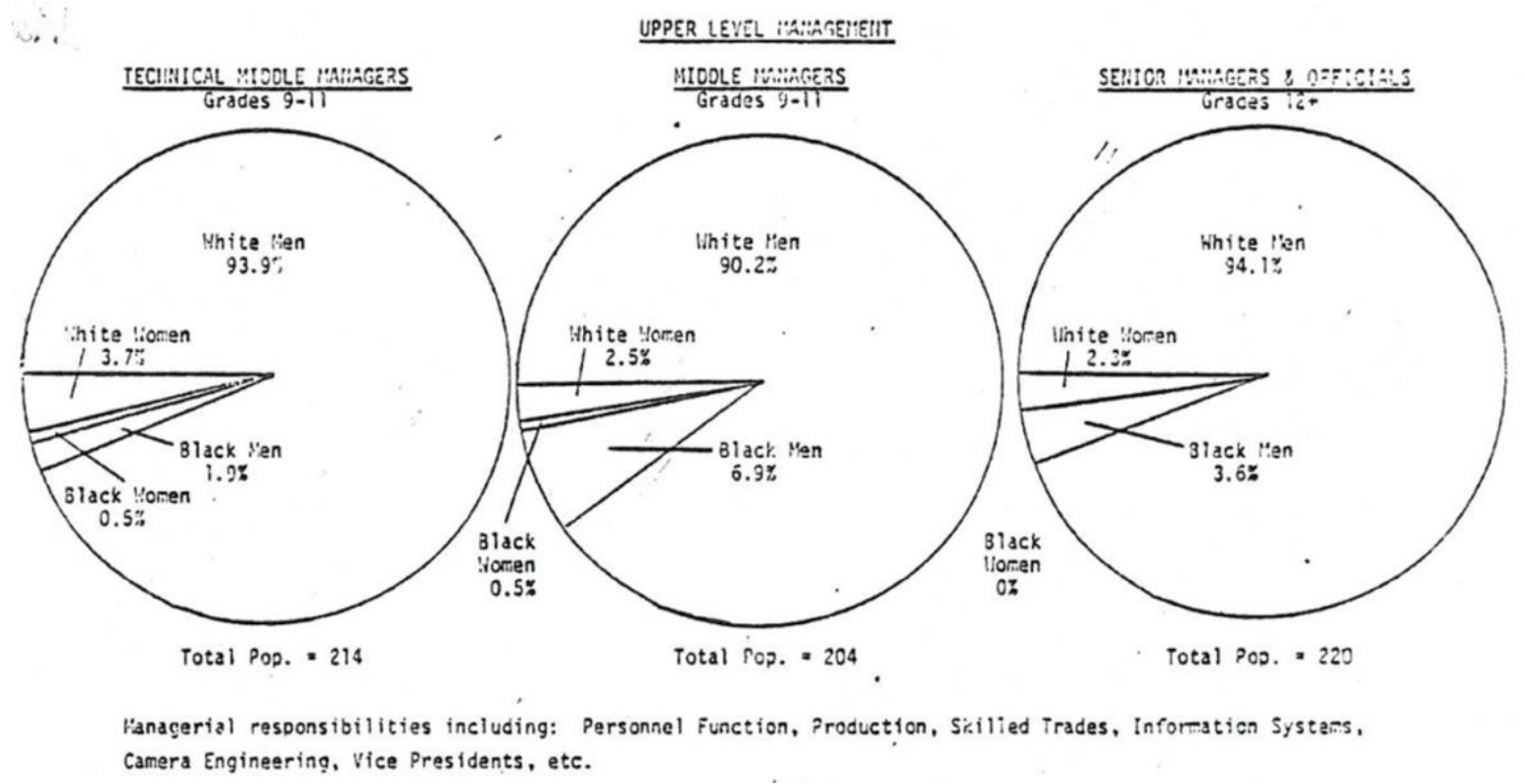

Figure 7. Three pie graphs titled "Upper Level Management." (Source Harvard Business School Archives ibid., IX4).

Polaroid's affirmative action reports are cultural artifacts of modern knowledge (Riles 2000). Through data visualizations these documents shape institutional understandings of race and racism. First, through these graphs, HR professionals make racial hierarchies and segregation within and across occupational grades visible and meaningful. Additionally, insofar as these practices are regarded as necessary to comply with affirmative action mandates, graphical representations of race make some organizational practices actionable and compel their enactment. In other words, in the context of compliance, HR professionals could not publish these graphical representations of race without simultaneously demonstrating how they were hiring and employing individuals "without regard to race." Such a relationship between data visualization, meaning, and action, suggests that Polaroid is not only concerned with being seen - and evaluated - as a racially diverse company, but as one that is making efforts to address racial inequality in the workplace. Second, insofar as these graphs are intended to produce understandings of how individuals are employed without regard to race, creed, color, or national origin, they reproduce liberal understandings of racial inequality that equate racism with a lack of equal opportunity. In what follows, I illustrate how diversity professionals extend these practices in producing graphical representations of race to compel corporate managerial professionals and executives to diversify leadership roles.

\section{Diversity Professionals' Corporate Leadership Reports}

In the 1980s, as many affirmative action practices became systemically dismantled through federal legislation and the withdrawal of resources from compliance offices, diversity management emerged as a field of business expertise. Yet, the boundaries between these two as separate fields of work are not easily discernable; as critical management scholars have shown, diversity professionals continue to employ practices once characterized as part of everyday affirmative action programming, including training and 
mentorship (Kelly and Dobbin 1998). Additionally, in the 21st century, diversity professionals publish demographic reports online to draw attention to a lack of racial and gender representation in corporate leadership, namely among executives and board members. Such demographic data are readily available on company websites, Security Exchange Commission annual reports, and in biographies published on LinkedIn, Reuters, Bloomberg, Forbes, and other business magazines. While conducting ethnographic field research at American D\&I headquarters, I observed that interns and paid researchers analyzed the data and produced an annual demographic report that contained over forty pages of tables and bar and pie graphs with limited text. This report was published almost every year between 2014 and 2020 .

In 2016, I learned that Maria, a research intern, was writing a paper entitled "Workforce Diversity and Corporate Governance." The Chairman of the Board had hired her for the summer specifically to write this report on the demographics of executives and board members of a select group of Fortune 1000 companies. His goal was to circulate the report widely at no charge to encourage diversity professionals to address racial and gender inequalities at work, as well as to promote American D\&I consulting services to help them achieve these goals. While many demographic reports from audit companies, such as McKinsey and Company, correlated representation to financial performance to promote diversity as a value, Maria's report did not do this. It was, rather, a 30-page PDF with dozens of pie and bar graphs and tables that only illustrated racial, ethnic, and gender demographics.

Maria's report showed that most executives and board members across the one hundred Fortune 1000 companies were white men - a fact that surprised no one, including her. In an interview, however, she said that what surprised her was that most of these companies had diversity and inclusion statements on their websites, wherein they claimed to value diversity - and that learning this fact shaped her orientation to the report. She said that the report sent these companies an implicit message of "We want you to do better" and to others, "If you weren't listed in this [report] it means you did so badly [that] we didn't even include you." She summarized, "[This] is a call to action for these companies to improve diversity in their leadership positions...it's for [them] to see that [they] are not matching the standards that [they] have set."

Made up mostly of data visualizations, American D\&I demographic reports enable bureaucrats, such as human resource professionals, diversity officers, as well as administrators, to digest a large amount of information in a time-efficient manner. Maria said that she modeled her demographic report after others published by reputable diversity organizations, including Catalyst and the Hispanic Association on Corporate Responsibility ( $\underline{\mathrm{HACR}})$. She reproduced some of their data visualizations to support her own, such as one by Catalyst, which illustrated gender demographics of S\&P 500 companies as a pyramid divided into 6 layers (see figure 8). This pyramid displayed the representation of women decreased as organizational ranking increased. Maria adapted this graphic into a more detailed pie chart, including race (see figure 9). She categorized demographic data in terms of "minority women," "minority men," "white women," and "white men." These graphs displayed white women as the largest nonwhite male group represented in executive leadership, followed by "minority men" and finally "minority women," suggesting the effects of intersectional oppression on women of color (Crenshaw 1990). 


\section{CATALYST PYRAMID WOMEN IN S\&P 500 COMPANIES}

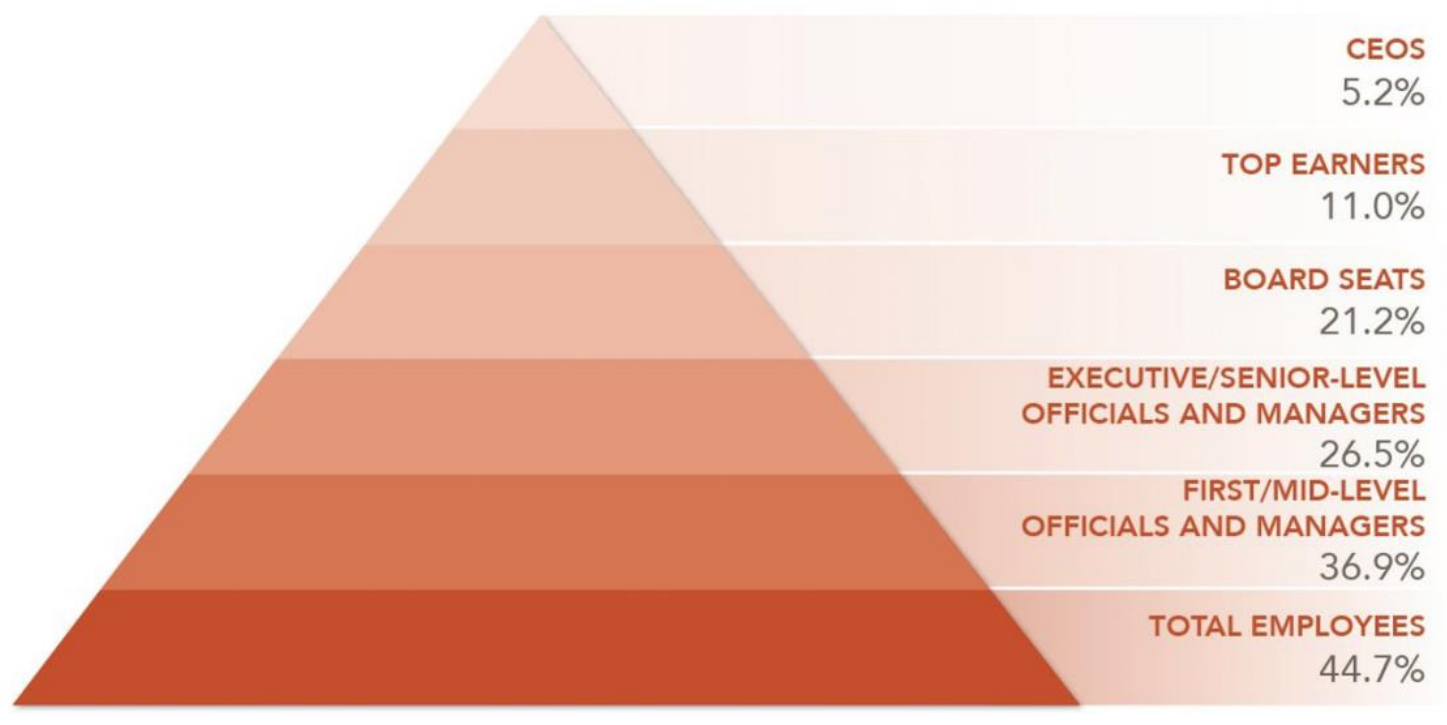

Figure 8. Pyramid graph titled "Women in S\&P 500 Companies" (Source Catalyst 2016).

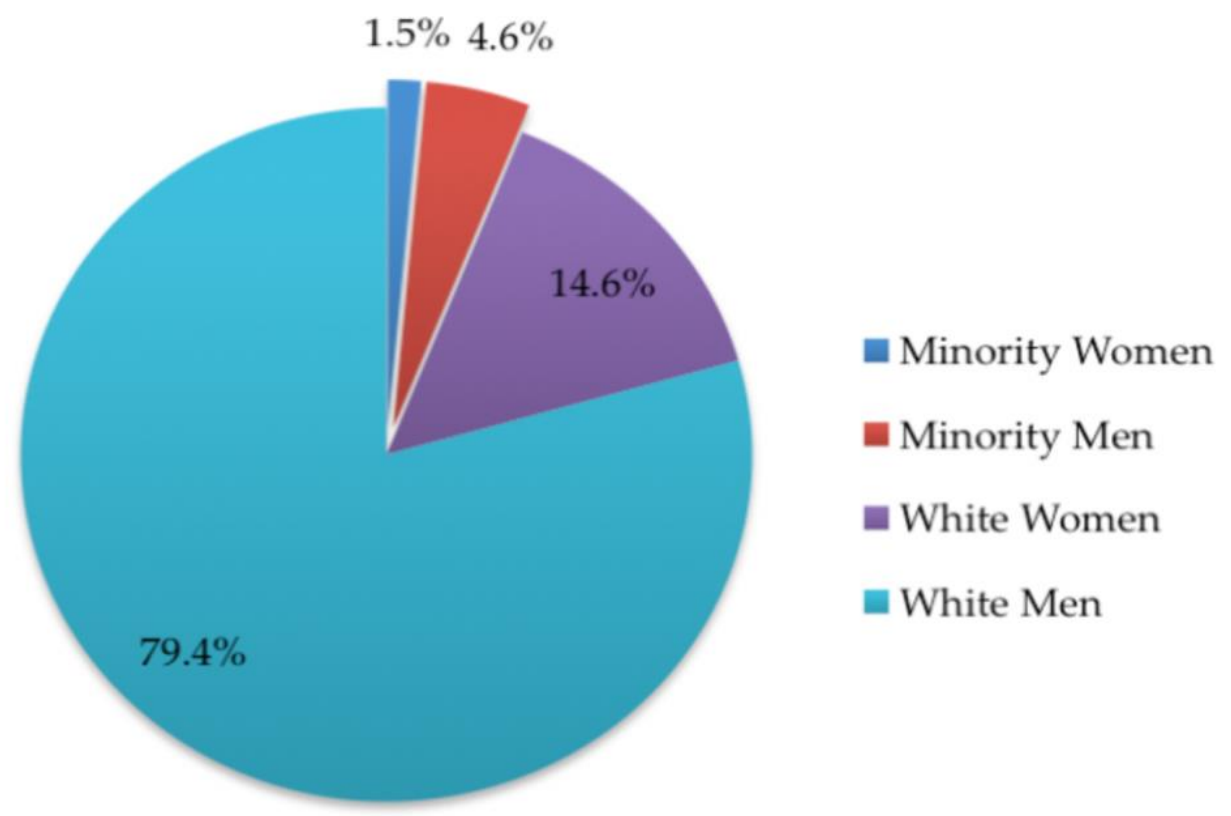

Figure 9. Pie graph titled "Executive Leadership Demographics in Companies with Diversity and Inclusion Statements." (Source American D\&I 2016). 
A significant number of graphs also compared corporate leadership demographics to city and national US demographics; a tactic that reminded me of Polaroid's affirmative action reports. I asked Maria why she chose to compare data in this way. She said that she was asked to do so in a presentation to American D\&I's Board of Directors. She reflected on the meeting, "They weren't really surprised at the data - they were like 'Yeah we expected that.'" So, she said, they asked her to do more comparative analyses: "They said, 'Alright maybe [companies are] not meeting the standards for matching representation in all of America, maybe [they're] matching representation within [their] county.' And we found that wasn't the case at all." She said that regardless of the standard used to measure it, racial and gender representation was too low.

Maria referenced a graph that depicted underrepresentation produced by the Hispanic Association on Corporate Responsibility, which she cited. The graph had three bars representing three years, each labeled with that year's percentage of the Hispanic/Latino population in the United States, and a dot placed on top, labeled with the percentage of board seats held by Hispanics/Latinos that year (see figure 10). Maria said that the design, "draws the reader's eye to the exact point they want to make: there's a discrepancy here and representation is disproportionate - it doesn't leave any question about it." Additionally, she explained, the reader could see inequality increase each year as the dot was placed closer and closer to the bottom of the bar, which only got taller. Similarly, Maria compared company leadership demographics with their specific county demographics, separating Hispanic or Latino category as a nonwhite group (see figure 11).

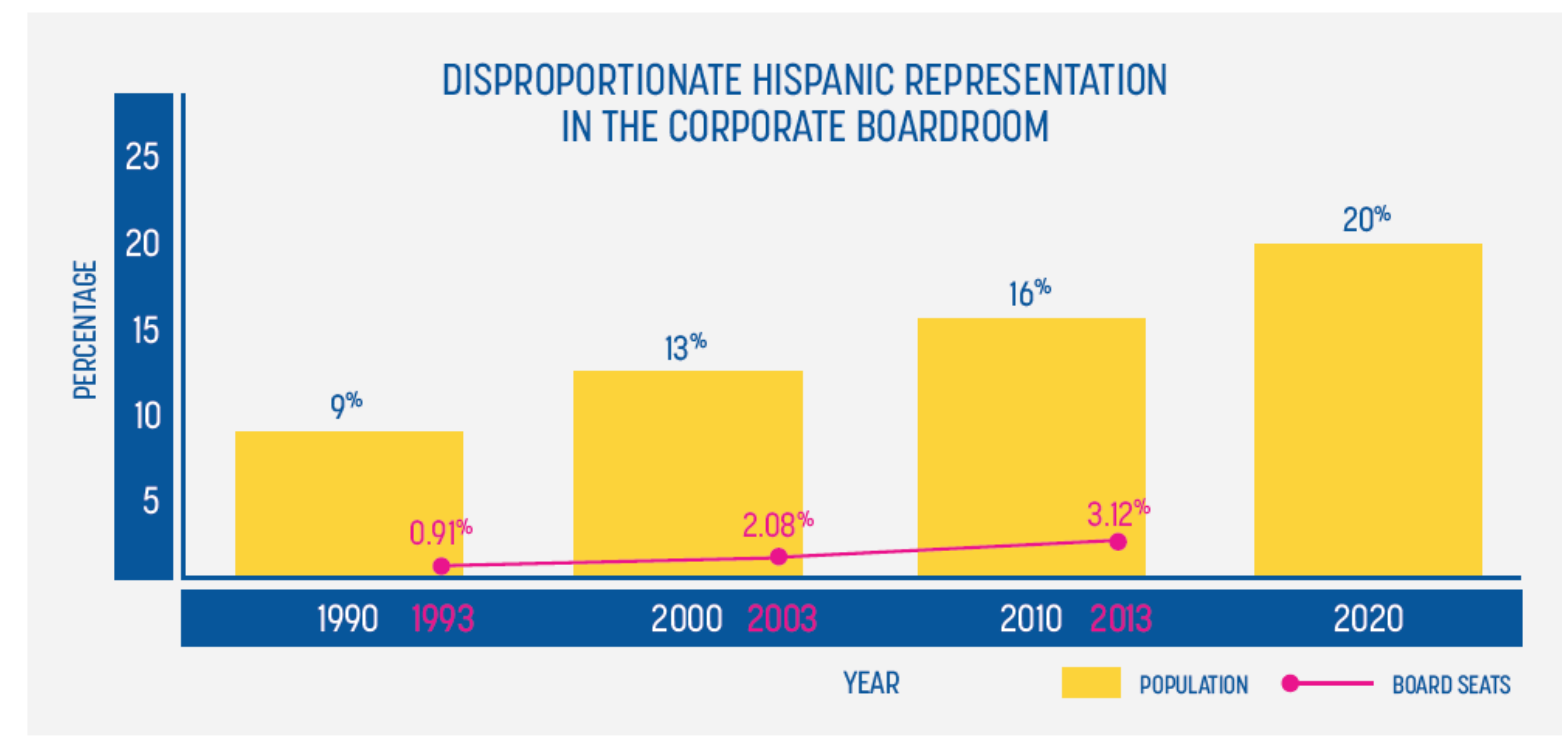

Figure 10. "Disproportionate Hispanic Representation in the Corporate Boardroom." Corporate Governance Study, $\underline{2013}$ (Source Hispanic Association on Corporate Responsibility). 


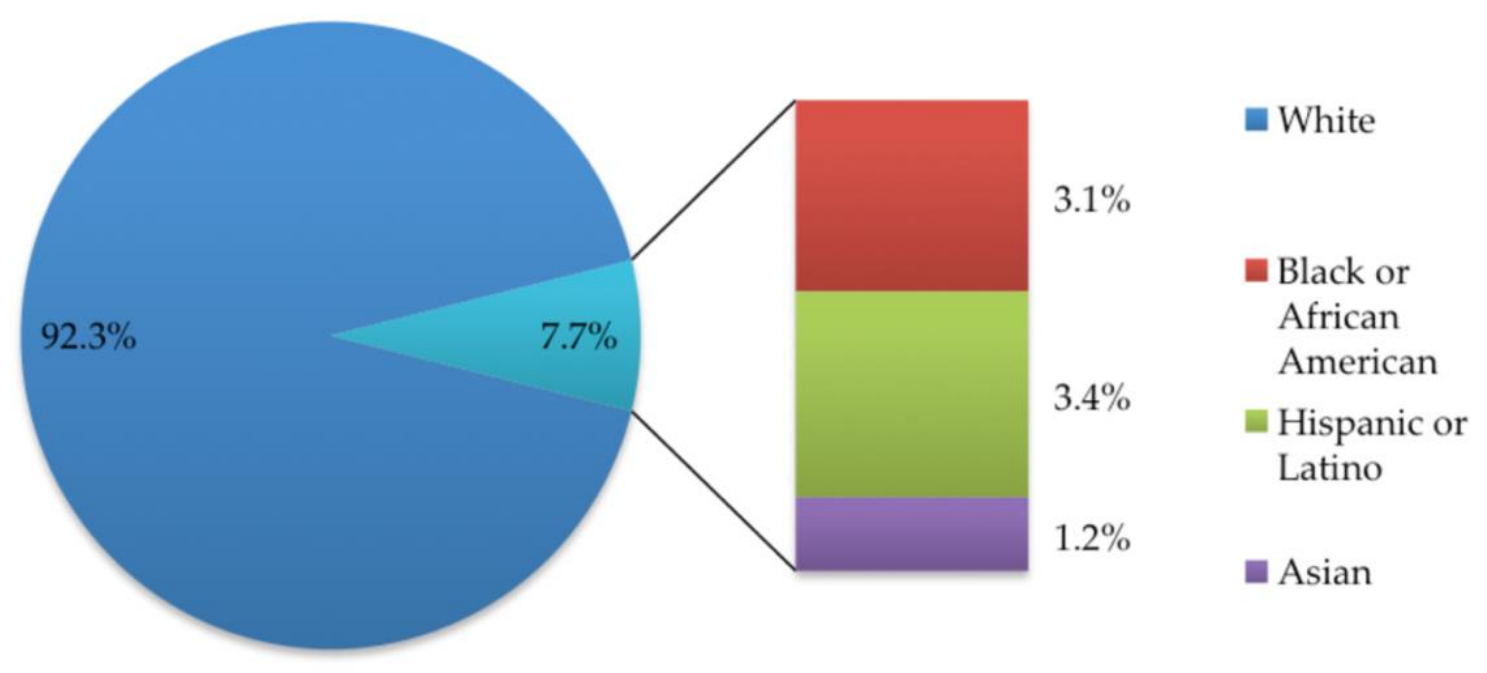

Figure 11. Pie and bar graph titled "Demographics of Executive Leadership and Board Positions in [One] County." (Source American D\&I 2016).

For diversity professionals it matters that gender and racial representation among executives and board members does not equal that of the population. I asked Maria what this meant for the readership. She said, "Well there's this assumption that if you have a certain amount of population like 50\% female, that you should have that same amount of proportion in leadership." I asked her if she knows why people tend to share this expectation. She responded,

People assume that there would be more fairness towards those people. I am not sure in terms of making the lives of the workers better or ... [if this would signify that] everyone has an equal chance of rising to a level of leadership as everyone else.

In other words, she suggested, people have hope that if there were more women and people of color in leadership that these individuals could advocate for their shared interests. Alternatively (or additionally), if readers saw that population demographics equaled leadership demographics, then it could mean to them that "People [of color] [already] have the same opportunities to rise [to] success as white people."

In essence, Maria's visuals and explanations demonstrate how these graphical representations of race are related meaningfully to equal opportunity. For instance, differences in the height of two bars or the size of a segment in a pie graph indexes underrepresentation and signifies inequality. In contrast, the idea of graphs depicting bars of similar heights or a pie with equal sized segments indexes equal representation across race, and in essence, signifies the existence of equal opportunity and the achievement of equality. Within a hierarchical bureaucratic structure, such as the corporation, this means having the opportunity to be considered for promotions, or to put it in simpler terms, the ability to become a corporate executive if one chooses. Thus, through these graphs, bureaucrats produce and reproduce a popular and liberal understandings of racism framed and defined by equal opportunity as a cultural value. 
Moreover, through the mass production and circulation of graphical representations of race, diversity professionals construct objective understandings of racism. For instance, at American D\&I I learned that every year, diversity professionals categorize, enumerate, and analyze over one-thousand corporate leadership positions and with the click of a button transform this data into bar and pie graphs that highlight the differences in white and nonwhite populations broken down by gender. Diversity professionals use software that enables them to analyze large data sets, produce dozens of graphs, and publish demographic reports. Data visualizations that depict racial representation across hundreds of corporations, convey an aura of objectivity about the existence of systemic racism. Data visualizations, in effect, help construct systemic racism as a social fact, as racial underrepresentation is seen as not one company's or industry's problem, but as a systemic issue across the United States.

Lastly, drawing on lessons she acquired in political science courses, Maria explained that these graphs do not just make information accessible; by choosing what data to visualize, she said, "You can present the information in a different way that may lead to it fitting your argument better, as opposed to just showing the data in a block of text." They are a way, she said, to "skew your argument better." Here, her argument was her interpretation of these graphs: insofar as these companies claimed to value diversity, they need to invest in programming that can increase racial and gender representation in leadership positions. In one of the first pages, Maria ranked companies according to representation, in effect, both shaming and celebrating companies publicly to compel them to change or continue supporting women and people of color in their firms. In an information age, corporations regularly display concern with their brand image. Knowing this, diversity professionals produce these graphical representations of race to compel diversity and other corporate professionals, including executives, to adopt diversity practices. Yet, in doing so diversity professionals often equate equal opportunity in the corporate firm with racism. Such data visualization practices, I will explain, mask whiteness and reproduce systemic racism.

\section{Masking Whiteness, Capitalist Firms, and Cultural Processes}

For people of color, employing positivist strategies can be a means to an end, as it allows individuals to legitimize their marginalized knowledges and themselves as people (Collins 2000; Hatch 2020). Similar to W. E. B. Du Bois, corporate bureaucrats produce and employ graphical representations of race to make whiteness visible and to work towards achieving racial integration. Such efforts are also markedly distinct, however, as Du Bois and his contemporaries sought to create a democratic society in the United States, corporate bureaucrats seek to enable individuals to pursue their social and economic self-interests through employment in capitalist firms. As I have shown, graphical representations of race help create popular understandings of racism and compel the enactment of culturally situated practices that are regarded to address racial inequalities. However, insofar as these practices equate equal opportunity with addressing racism, I argue, they also mask whiteness.

Whiteness is reproduced through institutional norms that create white privilege and racial hierarchies. Critical diversity scholars have shown that diversity practices, which include training and creating mentorship programs, reproduce whiteness in a number of ways, including by positioning white men as the ideal employee and by "fixing" marginalized persons to conform to white business cultures (Benjamin 2019; Grimes 2002; Nkomo 1992; Nkomo and Al Ariss 2014). Here, by focusing on diversity professionals' work I suggest that in equating racism with the absence of equal opportunity in corporate 
firms, graphical representations of race in the corporation help reproduce whiteness by naturalizing two major cultural processes: the operation of American capitalist ideologies that depict how white-collar labor markets are purported to function and the reproduction of systemic racial hierarchies that are embedded in the structure of capitalist firms.

Over half a century after the passage of the 1964 Civil Rights Act, diversity professionals argue through the graphical representation of race that equal opportunity in the workplace has not been achieved. Popularly, they also develop trainings, produce academic and popular literature, and tools to address what they term as "unconscious biases." According to most diversity professionals, this refers to underlying attitudes and stereotypes that often unintentionally lead employers to discriminate along racial, gender, and other lines, and which infringe on the ability of individuals to be hired and promoted on their own merit.4 In lieu of relying on federal regulation to address these issues, diversity professionals work to convince corporate employers to address biased hiring practices as a business imperative. However, in efforts to remove bias, they can also end up creating diversity tools that reproduce whiteness. For instance, while conducting fieldwork research, I heard diversity professionals regularly mention an academic article in trainings and workshops concerning the "whitening" of Black and Asian American resumes. Most salient to these diversity professionals was that, when racial markers were removed, candidates received more than two times the number of calls for interviews (Kang et al. 2016). Advocates claim that by removing names, demographics, and education information employers could focus on hiring based on skills and avoid unintentionally discriminating by race. ${ }^{5}$ While it may result in more diverse hires, removing racially identifying information from resumes is still a form of whitening, as without specific markers candidates of color can appear as a "normal" hire (ibid). Thus, blind resumes can effectively filter for candidates of color that are able to pass as white.

At its core, diversity professionals argue for the ability of white-collar workers of all races and genders to compete in labor markets that purport to value merit and talent without the influence of bias. ${ }^{6}$ Scholars of capitalism have shown that capitalist practices, norms, and ideologies are culturally and historically situated in the emergence of Western, that is, white societies, and as such are racial and gendered (Yanagisako 2002; Hirschman 1977; Robinson 1983; Arciniega 2020). Here, I have shown how the employment of equal opportunity as a liberal value in capitalist firms is driven by desires for socio-economic inclusion in the United States. Diversity professionals' attempts to create unbiased labor markets reveal that neoliberal capitalist ideologies continue to be reproduced in racial and gendered ways. For instance, while

\footnotetext{
${ }^{4}$ At the time of submitting this paper for publication, a quick internet search for "unconscious bias + race" produced more than 10 million results.

${ }^{5}$ As of publication of this article, diversity practitioners advocate for employing blind resumes, diversifying hiring committees, and actively diversifying the candidate pool as practices employers could undertake to increase diversity through hiring. For example, see Bortz 2018. For a discussion of algorithms and diversity efforts in creating blind resumes, see Ruha Benjamin (2019).

${ }^{6}$ As explained by Richard Sennett (2007), as part of the emergence of the "new culture of capitalism," in the late 2oth century values of merit and talent displaced those of craftsmanship and achievement and flexible labor became seen as an epitome of white-collar freedom and individuality.
} 
diversity professionals admit that it is not devoid of cultural biases, they do not challenge the free market economy as inherently contradictory to their efforts. Rather, they posit that the unhindered pursuit of selfinterest is an unfulfilled post-civil rights promise. Thus, the graphical representation of race helps diversity professionals normalize key values that are essential to the reproduction of neoliberal capitalist ideologies, including meritocracy, free markets, self-interest, and the possibility for unlimited economic growth. This everyday normalization is driven by desires, aspirations, and goals, which emerge from negotiating a legacy of systemic racism with what it means to be included in capitalist firms and in the United States more broadly.

Moreover, at a time when the compensation of the average Chief Executive Officer has eclipsed that of the average worker, corporate bureaucrats attempt to create a resemblance of the corporate ladder to achieve high-ranking managerial positions. ${ }^{7}$ They also advocate for pay equity, insisting that white-collar professionals, including executives, should achieve the compensation (salaries, bonuses, and incentives) that corresponds to what is a market rate for their roles. While conducting fieldwork, I rarely witnessed discussions of executive compensation with the exception of two events. Once, was when I asked the Chief of the Board of American D\&I what he thought about a specific Latino executive having made 6 million dollars in 2014. He responded by calling him "smart." ${ }^{8}$ The second was in winter 2015 at American D\&I, when one day I heard whispers from event coordinators as they speculated on the compensation of the executive of the firm, contrasting it with the $\$ 30,000$ salary they made each year. Thus, insofar as they employ graphical representations of race in ways that equate addressing racism with increasing equal opportunity in the firm, diversity professionals and corporate bureaucrats help naturalize systems of unequal pay, the division and segmentation of labor, and top-down management structures. The employment of graphical representations of race in and through capitalist cultural processes, in effect, reproduce structures of racial inequality.

\section{Conclusion}

In the 21st century, graphical representations of race are mundane: they are a means to understand institutional, local, regional, state, and global racial disparities. Activists have long employed these data visualization practices to advocate for liberation, civil rights legislation and more recently to urge corporations to act on their verbal commitments to diversity and inclusion and racial justice. In this paper, I explored how corporate bureaucrats extend a Du Boisian legacy in constructing popular understandings of race and racism. I drew together Du Bois's and corporate bureaucrats' data visualization practices, examining how graphical representations of race operate as both epistemic and semiotic objects. I showed how by employing equal opportunity as a liberal value, corporate bureaucrats create meaningful change that can provide white-collar workers of color and women with equal opportunity in the workplace. I argued that

\footnotetext{
7 One major study revealed that CEO compensation grew 940\% since 1978, compared to the typical worker (in production and nonsupervisory roles) which grew $12 \%$, see Mishel and Wolfe (2019).

${ }^{8}$ In an ethnography, Karen Ho (2009) depicts how characterizing powerful economic actors as "smart" helps legitimize capitalist institutions, such as in the case of investment bankers and Wall Street.
} 
graphical representations of race can meaningfully challenge racial inequalities, yet insofar as they equate equal opportunity in capitalist firms with addressing racism, they mask whiteness and reproduce systemic racism.

The graphical representation of race reveals how the processes of signification and epistemic knowledge production are entangled in everyday bureaucratic practices. Through data visualization practices, corporate bureaucrats operate and mobilize race and racism at the boundaries of business and social justice. These visual and rhetorical strategies reveal how mundane racial materiality, such as the graphical representations of race, does certain kinds of culturally situated work: they compel the enactment of new practices seen to address specific understandings of racism, as well as reproduce racial and gendered hierarchies. More research, however, needs to be conducted to examine how data visualizations compel specific kinds of change that can challenge and/or reproduce whiteness and systemic racial and gender inequalities through culturally situated processes.

In attempts to propose alternatives that can make best use of the potential of graphical representations of race for compelling change, I draw inspiration from Catherine D'Ignazio and Lauren F. Klein (2016) and standpoint theorists who have asked us to embrace feminist approaches to data visualization to create meaningful social impact. In efforts to challenge liberal ideologies embedded in capitalist structures and cultures, I suggest that we consider how these practices can be used to empower collectives, rather than individuals. I also urge us to situate, localize, and employ transparency over the partiality of such projects and to embrace a diversity (plurality) of strategies for challenging systemic racism. For instance, while diversity practices are often critiqued for their reproduction of racism, it would be an error to overlook how they create opportunities for people of color in the workplace every day. In other words, we can learn much of what practices have the potential to challenge racism within and beyond our places of work by situating such practices not only as inevitable failures but as mundanely productive. One way to do this is by examining how work, including purportedly antiracist data visualization, gets done at the intersections of social justice and business.

\section{Acknowledgements}

Thank you to Dr. Melissa Maceyko for her invaluable comments and feedback on this manuscript. Thank you to the reviewers for their attention to critique and to the editors of the journal for the care with which they read and edited this work.

\section{Author Biography}

Luzilda Arciniega is an independent scholar and practitioner on diversity and inclusion. She was previously Visiting Assistant Professor at Wayne State University, and an opinion author and co-editor of the Association for Political and Legal Anthropology section in Anthropology News, the American Anthropology Association's main newsletter.

\section{References}

African American Photographs for 1900 Paris Exposition (LOTs 11293-11308 and 11930-11932). Prints \& Photographs Division [reproduction number, e.g., LC-USZ62-1234]. Library of Congress, 
Washington D.C. 20540-4730. Accessed January 7, 2020. https://www.loc.gov/collections/africanamerican-photographs-1900-paris-exposition/about-this-collection/

Ahmed, Sara. 2012. On Being Included: Racism and Diversity in Institutional Life. Durham: Duke University Press. Ahmed, Sara. and Elaine Swan. 2006. "Doing Diversity." Policy Futures in Education 4(2): 96-100.

Allen, Jafari S. and Ryan C. Jobson. 2016. "The Decolonizing Generation: (Race and) Theory in Anthropology since the Eighties." Current Anthropology 57(2): 129-48.

Amann, Klaus and Karin Knorr-Cetina. 1988. "The Fixation of (Visual) Evidence." Human Studies 11: 133-169. American D\&I. 2016. Workforce Diversity and Corporate Governance.

Arciniega, Luzilda C. 2020. "Selling Diversity to White Men: How Disentangling Economics from Morality is a Racial and Gendered Performance." Organization (2): 228-246.

Battle-Baptiste, Whitney and Britt Rusert, eds. 2018. W. E. B. Du Bois's Data Portraits: Visualising Black America. Massachusetts: Chronicle Books.

Benjamin, Ruha. 2019. Race after Technology: Abolitionist Tools for the New Jim Code. Cambridge: Polity Press.

Berrey, Ellen. 2015. The Enigma of Diversity. Chicago: The University of Chicago Press.

Beunza, Daniel, and David Stark. 2004. "Tools of the Trade: The Socio-Technology of Arbitrage in a Wall Street Trading Room." Industrial and Corporate Change 13(2): 369-400.

Bond, Sarah. 2017. "How Is Digital Mapping Changing The Way We Visualize Racism and Segregation?" Forbes, October 20, 2017. Accessed June 7, 2020. https://www.forbes.com/sites/drsarahbond/2017/10/20/how-is-digital-mapping-changing-theway-we-visualize-racism-and-segregation/?sh=3dd1a98233fa.

Bortz, Daniel. 2018. "Can Blind Hiring Improve Workplace Diversity?" Society for Human Resource Management, March 20, 2018. https://www.shrm.org/hr-today/news/hrmagazine/0418/pages/can-blind-hiring-improve-workplace-diversity.aspx.

Buiani, Robert. 2014. "Innovation and Compliance in Making and Perceiving the Scientific Visualization of Viruses." Canadian Journal of Communication 39(4): 539-556.

Burri, Regula V. 2012. "Visual Rationalities: Towards a Sociology of Images." Current Sociology 60(1): 45-60.

—, and Joe Dumit. 2008. "Social Studies of Scientific Imaging and Visualization." In The Handbook of Science and Technology Studies, edited by Edward J. Hackett, Olga Amsterdamska, Michael E. Lynch, and Judy Wajcman, 297-317. Cambridge: MIT Press.

Calvillo, Nerea. 2019. "Digital Visualizations for Thinking with the Environment." In DigitalSTS, edited by Janet Vertesi and David Ribes, 61-76. Princeton: Princeton University Press.

Cambrosio, Alberto, Daniel Jacobi, and Peter Keating. 2005. "Arguing with Images: Pauling's Theory of Antibody Formation." Representations 89(1): 94-130.

Catalyst. 2016. "Women in S\&P 500 Companies." Catalyst. August 222017. https://www.catalyst.org/research/women-ceos-of-the-sp-500/.

Collins, Patricia H. 2000. Black Feminist Thought: Knowledge, Consciousness, and the Politics of Empowerment. New York: Routledge.

Coopmans, Catelijne, Janet Vertesi, Michael E. Lynch, and Steve Woolgar. 2014. Representation in Scientific Practice Revisited. Cambridge: MIT Press. 
Crenshaw, Kimberlé. 1990. "Mapping the Margins: Intersectionality, Identity Politics, and Violence Against Women of Color." Stanford Law Review 43: 1241.

Doucet-Battle, James. 2016. "Bioethical Matriarchy: Race, Gender, and the Gift in Genomic Research." Catalyst: Feminism, Theory, Technoscience 2(2): 1-28.

D'Ignazio, Catherine, and Lauren F. Klein. 2016. "Feminist Data Visualization." Paper presented at the Workshop on Visualization for the Digital Humanities, Baltimore. https://dspace.ceid.org.tr/xmlui/bitstream/handle/1/955/Feminist Data Visualization.pdf.

Du Bois, W. E. B. 1899. The Philadelphia Negro. Philadelphia: University of Pennsylvania.

—.1900. "The American Negro at Paris." American Monthly Review of Reviews 22 (5): 575-577.

Dumit, Joe and Marianne de Laet. 2014. "Curves to Bodies: The Material Life of Graphs." In Routledge Handbook of Science, Technology, and Society, 93-112. London and New York: Routledge.

El-Erian, Mohamed. A. 2016. The Only Game in Town. New York: Random House.

Frazer, Franklin E. 1932. The Negro Family in Chicago. Chicago: The University of Chicago Press.

Garnett, Emma. 2016. "Developing a Feeling for Error: Practices of Monitoring and Modelling Air Pollution Data." Big Data \& Society 3(2): 1-12.

Gilmore, Ruth W. 2007. Golden Gulag. Berkeley: University of California Press.

Gordon, Avery. 1995. "The Work of Corporate Culture: Diversity Management." Social Text 44(3): 3-30.

Grimes, Diane S. 2002. "Challenging the Status Quo?: Whiteness in the Diversity Management Literature." Management Communication Quarterly 15(3): 381-409.

Guzman, Jessie P., ed. 1947. Negro Year Book, 1941-1946. Tuskegee: The Negro Year Book Publishing Company.

Hankins, Thomas L. 2000. "Blood, Dirt, and Nomograms" CHANCE 13(1): 26-37.

Haraway, Donna. 1997. Modest_Witness@Second_Millennium.FemaleMan_Meets_OncoMouse. New York: Routledge Press.

Hatch, Anthony R. 2020. "Du Boisian Propaganda, Foucauldian Genealogy, and Antiracism in STS Research." Engaging Science, Technology, and Society 6: 58-65.

Hentschel, Klaus. 2014. Visual Cultures in Science and Technology: A Comparative History. Oxford: Oxford University Press.

Hirschman, Albert 0. 1977. The Passion and the Interests: Political Arguments for Capitalism Before Its Triumph. Princeton: Princeton University Press.

HACR Research Institute. 2013. Corporate Governance Study. Hispanic Association on Corporate Responsibility. https://www.hacr.org/latinos-on-corporate-boards/.

Ho, Karen. 2009. Liquidated: An Ethnography of Wall Street. Durham: Duke University Press.

Kaiser, David. 2005. Drawing Theories Apart: The Dispersion of Feynman Diagrams in Postwar Physics. Chicago: University of Chicago Press.

Kang, Sonia K., Katherine A. DeCelles, András Tilcsik, and Sora Jun. 2016. "Whitened Résumés: Race and SelfPresentation in the Labor Market." Administrative Science Quarterly 61(3): 469-502.

Knorr-Cetina, Karin and Klaus Amann. 1990. "Image Dissection in Natural Scientific Inquiry." Science, Technology, \& Human Values 15(3): 259-83.

Keane, Webb. 2003. "Semiotics and the Social Analysis of Material Things." Language \& Communication $23(3-4): 409-25$. 
Kelly, Erin and Frank Dobbin. 1998. "How Affirmative Action Became Diversity Management: Employer Response to Antidiscrimination Law, 1961 to 1996." American Behavioral Scientist 41(7): 960-84. Latour, Bruno. 1987. Science in Action. Cambridge: Harvard University Press.

—.1990. "Drawing Things Together." In Representation in Scientific Practice, edited by Michael Lynch and Steve Woolgar, 19-68. Cambridge: MIT Press.

—

Lynch, Michael. 1985a. Art and Artifact in Laboratory Science: A Study of Shop Work and Shop Talk in a Research Laboratory (1st ed.). London: Routledge. https://doi.org/10.4324/9781315111285

—1985b. "Discipline and the Material Form of Images: An Analysis of Scientific Visibility." Social Studies of Science 15(1): 37-66.

—

MacKenzie, Donald. 2013. "Visible, Tradeable Carbon: How Emissions Markets Are Constructed." In Imagining Organizations, edited by Paolo Quattrone, Nigel Thrift, Chris Mclean, and Francois-Regis Puyou. 63-90. London: Routledge.

M'charek, Amade. 2013. "Beyond Fact or Fiction: On the Materiality of Race in Practice." Cultural Anthropology 28(3): 420-42.

Melamed, Jodi. 2006. "The Spirit of Neoliberalism: From Racial Liberalism to Neoliberal Multiculturalism." Social Text 24 (4 (89)): 1-24.

Mishel, Lawrence, and Julia Wolfe. 2019. "CEO compensation has grown 940\% since 1978" Economic Policy Institute, August 19. https://www.epi.org/publication/ceo-compensation-2018/.

Mohanty, Chandra T. 2003. Feminism Without Borders. Durham: Duke University Press.

Munn, Nancy D. 1986. The Fame of Gawa. Durham: Duke University Press.

Nkomo, Stella M. 1992. "The Emperor Has No Clothes: Rewriting 'Race in Organizations.'" Academy of Management Review 17(3): 487-513.

— Journal of Managerial Psychology 29(4): 389-404.

Noble, Safiya U. 2018. Algorithms of Oppression. New York: New York University Press.

Office of Federal Compliance Programs. 2020. "History of History of Executive Order 11246." Accessed July 22, 2020. US Department of Labor. https://www.dol.gov/agencies/ofccp/about/executive-order11246-history.

Omi, Michael, and Howard Winant. 2014. Racial Formation in the United States. New York: Routledge.

Peirce, Charles S. 1958. Collected Papers of Charles Sanders Peirce. VIII, edited by Arthur. W. Burks. Cambridge: Harvard University Press.

Pryke, Michael. 2010. "Money's Eyes: The Visual Preparation of Financial Markets." Economy and Society 39(4): 427-59.

Polaroid Corporation Records. 1970. Series I. Administrative Records, circa 1930-2005. "Equal Employment Opportunity: A Report on the Polaroid Program for 1969." Box: I.388, Folder: 9. Baker Library, Harvard Business School. Boston: Massachusetts. 
Polaroid Corporation Records. 1979. Series I. Administrative Records, circa 1930-2005. "Polaroid Corporation Corporate Affirmative Action Annual Report, July 1978-June 1979.” Box: I.390, Folder: 6. Baker Library, Harvard Business School. Boston: Massachusetts.

Pulido, Laura. 2000. "Rethinking Environmental Racism: White Privilege and Urban Development in Southern California." Annals of the Association of American Geographers 90(1): 12-40.

Quattrone, Paolo, Nigel. Thrift, Chris Mclean, and Francois-Regis Puyou. 2013. Imagining Organizations. London: Routledge.

Rheinberger, Hans-Jörg. 1997. Toward a History of Epistemic Things: Synthesizing Proteins in the Test Tube. Palo Alto: Stanford University Press.

Riles, Annelise. 2006. Documents: Artifacts of Modern Knowledge. Ann Arbor: University of Michigan Press.

Robinson, Cedric. 1983. Black Marxism: The Making of the Black Radical Tradition. London: Zed Press.

Rodríguez-Muñiz, Michael. 2016. "Bridgework: STS, Sociology, and the 'Dark Matters' of Race." Engaging Science, Technology, and Society 2: 214-216.

Roediger, David R. 1999. The Wages of Whiteness. New York: Verso.

Sennett, Richard. 2007. The Culture of the New Capitalism. New Haven: Yale University Press.

Smith, Shawn M. 2004. Photography on the Color Line. Durham: Duke University Press.

Spero, Sterling D., and Abram L. Harris. 1931. The Black Worker. Columbia University Press New York.

Thrift, Nigel. 2005. Knowing Capitalism. London: Sage Publications.

Thomas, R. Roosevelt. 1991. Beyond Race and Gender. New York: AMACOM.

Tilling, Laura. 1975. "Early Experimental Graphs." The British Journal for the History of Science 8(3): 193-213.

Tufte, Edward. 1997. "Visual Explanations: Images and Quantities, Evidence and Narrative." Connecticut: Graphics Press.

Vertesi, Janet. 2014. "Drawing as: Distinctions and Disambiguation in Digital Images of Mars." In Representation in Scientific Practice Revisited, edited by Catelijne Coopmans, Janet Vertesi, Michael Lynch, and Steve Woolgar, 15-36. Cambridge: MIT Press.

Woodson, Carter G. 1918. A Century of Negro Migration. Lancaster: Press of The New Era Printing Company. Work, Monroe N. 1922. Negro Year Book. Tuskegee: The Negro Year Book Publishing Company.

Yanagisako, Sylvia. 2002. Producing Culture and Capital: Family Firms in Italy. Princeton: Princeton University Press.

Zuberi, Tukufu. 2004. "W. E. B. Du Bois's Sociology: The Philadelphia Negro and Social Science." The ANNALS of the American Academy of Political and Social Science 595(1): 146-56. 